Language and Language Teaching Journal http://e-journal.usd.ac.id/index.php/LLT Sanata Dharma University, Yogyakarta, Indonesia

\title{
Revealing Pre-service Foreign Language Teachers' Imagined Professional Identity in Reflective Journals
}

\author{
Yuseva Ariyani Iswandari \\ Universitas Sanata Dharma \\ yuseva@usd.ac.id \\ DOI: https://doi.org/10.24071/11t.2017.200107
}

\begin{abstract}
This study reports types of imagined identities that pre-service foreign language teachers construct during their preparation of becoming teachers in a pre-service course named Micro Teaching. This course specifically facilitates pre-service teachers to implement some theories of teaching in the previous semesters into practice. Revealing what kinds of teachers they imagine in the future is believed to have greater impact on the pre-service teachers' professional development (Chong \& Low, 2009). The researcher analyzed 19 pre-service teachers' reflective journals to find out their imagined professional identities. The identities were then coded using the framework of imagined professional identity by $\mathrm{Xu}$ (2013) that fell into three categories: language expert, learning facilitator, and spiritual guide. The result showed that the three categories appeared in their reflective journals. However, the dominant imagined identity constructed throughout the semester was teachers as learning facilitators. It indicates that the pre-service teachers' concept of teaching is shifted from the traditional concept which emphasizes teacher control into recognition of self-initiated learning.
\end{abstract}

Keywords: teacher's imagined professional identity, pre-service foreign language teachers

\section{Introduction}

Learning to become a teacher is both complex and personal processes that involve many aspects (Olsen, 2010). Students enter formal teacher education program with a lot of personal knowledge and images, which are so much influenced by what they experienced during their many years of study in schools. Direct experience with their teachers in the past helps them construct and reconstruct the images of teachers that stay in their imagination. Furthermore, Beijaard (1995) states that good practices from their former teachers most often will strongly determine their attitude and their imagined professional identity beliefs about teaching. Therefore, the imagination of their identity as future teachers that they bring to the program is the internalization of the "images" they met previously.

This study mainly focuses on the formation of imagined professional identity that pre-service foreign language (FL) teachers construct during their initial preparation of becoming teachers in a course named Micro Teaching. This course specifically facilitates pre-service FL teachers to implement some theories of 
teaching in the previous semesters into practice in the small scope of class-based practicum before they have their teaching practice in real schools contexts. In foreign language context, there are at least two main challenges faced by teacher candidates. First, these students normally come to the class with little imagination on how a teacher should teach. It is because what they bring with them is the teaching concept that is merely based on the theories. The second is related to the complexities of learning the language and learning how to teach the language to their students (Darling-Hammond, 2008). These pre-service FL teachers are still on the stage of learning English. Learning English here means learning how to construct good and correct English sentences both in spoken and written form. Meanwhile, they are also required to fulfil some standards of teaching instructions, which include "performance-based, proficiency-based, and communicative-based instruction" (Burke, 2006). In order to know their growth of becoming FL students and their readiness of becoming FL teacher candidates, students are suggested to undergo continuous reflection on their own "journey" throughout their learning process.

The term reflection was firstly found and promoted by Dewey in 1933. In the context of FL teacher education program, reflection is vital for the candidates as it enables the students to see, evaluate, formulate, and reformulate their experience. During the reflection, they will be invited to take their time thinking about what they have done by looking at both the theories and practices. Therefore, it is important for the teacher education program to introduce and teach reflective practice to the students. It is believed that "reflective practice is considered as crucial and its development is the responsibility of all teacher educators - both at university and in the schools" (Walkington, p. 53). Thus, through the FL preservice teachers' weekly reflective journal, this study aims to reveal what kinds of teachers they imagine in the future in order to help them develop a roadmap for successful teacher development.

\section{Literature Review}

\section{Teacher's imagined professional identity}

The transition time from being students who only learn theories of teaching to becoming pre-service teachers who enter the teaching practice is often difficult. Therefore, understanding teachers' professional identity is very crucial as this can help them to become better aware of who they are as teachers and what kinds of teachers they want to be in the future. Gee (2000) defines identity as a person's image that is shaped by that person in a particular context and is seen by the person himself and others. The created image is influenced by the person's beliefs, values, attitude, and knowledge combined with perceptions of what is expected from others and self. In term of professional identity in teaching, Pillen, Brok, \& Beijaard (2013) state that "professional identity is not a stable product, but rather a continually changing, active, and on-going process" (p. 87). It requires teachers to define, redefine, and view their identity as they get into more teaching practice. Avalos and De Los Rios (2013) highlight that teachers' ability, the work commitment and responsibility, teaching quality and satisfaction, and the 
way others see them as a teacher determine the way they identify themselves as professionals.

A lot of studies on teacher identity in the pre-service stage focus more on the formation and transformation of professional identity. In fact, not all students who join teacher education program come with personal willingness to be teachers and equip themselves with sufficient content knowledge. Thus, helping them reveal their basic type of identity that is imagined professional identity is useful as to avoid identity tensions. The broad concept of imagined identities refer to "identities constructed in the individual's imaginations about the relationships between one's self and other people and things in the same time and space that he or she nevertheless has virtually no direct interactions with" (as cited in Xu, 2013, p. 80). The way teachers shape their imagined identities is from their unlimited imagination of practices they see and limited experiences they encounter, not on the real engagement in the practices where practiced identity is formed.

$\mathrm{Xu}$ (2013) suggests social cognition theories to analyze imagined identity features. Moscovici (2000) mentions that "social cognitions, of which professional is one kind, can be classified as based on rules, cues, exemplars, or schema" (as cited in Xu, 2013). The following is the further explanation on the classification of social cognitions:

Table 1: Social cognition classification by Moscovici (as cited in Xu, 2013, p. 80)

\begin{tabular}{|l|l|}
\hline Social cognition classification & \multicolumn{1}{|c|}{ Characteristics } \\
\hline Rule-based & $\begin{array}{l}\text { The identities are designated according to the professional rules } \\
\text { and regulations that have to be fulfilled by the teachers. }\end{array}$ \\
\hline Cue-based & $\begin{array}{l}\text { The identities are formed by considering some demonstrated } \\
\text { cues that lead the teachers to this classification. }\end{array}$ \\
\hline Exemplar-based & $\begin{array}{l}\text { The identities are adjusted with the examples that the teachers } \\
\text { see and consider as good examples. }\end{array}$ \\
\hline Schema-based & $\begin{array}{l}\text { The identities are formed by required norms in a certain cultural } \\
\text { context. }\end{array}$ \\
\hline
\end{tabular}

Using Moscovici's social cognition classification as the framework, $\mathrm{Xu}$ formed 3 categories of teachers' imagined professional identity, namely language expert, learning facilitator, and spiritual guide. Language expert focuses on content knowledge, which includes the ability of delivering the materials using good English and having good teaching methods (Xu, 2013). Learning facilitator, on the other hands, refers to a type of a teacher that pays more attention on students' learning process by becoming their facilitator. In this case, the preservice teachers imagine that teaching is more on facilitating students to achieve the best English learning and assisting the learning process. Spiritual guide is more related to "guiding students' minds, spirit, and pursuits" (Xu, 2013, p. 82). It means that the pre-service teachers imagine that they can become a good teacher with a good attitude and can guide the students to become good human being. Xu's 3 categories of teachers' imagined professional identity will be the framework of this study. 


\section{Pre-service foreign language (FL) teachers}

Becoming FL teachers, in this context English teachers, is considered more complex since the teachers do not only have to learn the language but also learn to teach the language to the students (Darling-Hammond, Grossman, Rust, \& Shulman, 2005). This fact is claimed to be the main cause of pre-service foreign language teachers' tension. Not all of them are ready with their English because they still struggle with grammar and language mechanics. At the same time, they have to make sure that the language they use is correct in the teaching practice class. The term correct here is not only when it is used to communicate, but also when it is used to explain the materials. This kind of conflicted situation, where they "feel" they are not able to use the language correctly, cause tension and doubt of becoming good teachers (Pillen, Brok, \& Beijard, 2013). This leads to the situation in which they lose their professional identity. Franzak (2002) has similar thought that "the practicum experience is often stressful for pre-service teachers because they encounter dissonance between their preconceived views of teacher and what they observe in the field" (p. 260). Therefore, introducing the concept of imagined professional identity will help them stay and survive in the teaching profession.

\section{Method}

This study used a qualitative approach in order to reveal what kinds of teachers the pre-service foreign language teachers imagine in the future. Ary et al. (2010) mention that "qualitative inquiry seeks to understand and interpret human and social behavior as it is lived by participants in a particular social setting" ( $p$. 420). The data were gathered through two major instruments, they were document analysis and interview as the data triangulation. The document analyzed by the researcher was 19 pre-service foreign language teachers' weekly reflective journals to find out their imagined professional identities. The identities were then coded using the framework of imagined professional identity by $\mathrm{Xu}$ (2013) that fell into three categories: (1) language expert, (2) learning facilitator, and (3) spiritual guide.

Next, unstructured interview was conducted in order to double check the participants' answers. This type of interview is believed to provide rich description from the participants (Heigham and Croker, 2009). The interview was aimed to triangulate the provided data in the participants' reflective journals to see how the participants' words and voices are interrelated. Triangulation refers to "validating data through comparison of two or more sources about the same phenomenon but gathered from different phases of the fieldwork" (in Heigham \& Croker, 2009). The questions generated in the interview were more or less about similar topics in the participants' reflective journals. The researcher created a natural conversation atmosphere during the interview so that the participants could freely share their experiences of professional learning and reveal their imagined professional identity. However, due to the limited access and time, the researcher only interviewed three participants. Nonetheless, the researcher believed that the data gathered from those three participants would be enough since those three showed high motivation and performance during the semester. 
As it was mentioned before, the 19 participants were students at one of the teacher education programs in an Indonesian university where English is a foreign language. Students who enrolled in this program are expected to be English teachers when they graduate. Therefore, they are provided with a great number of theories of teaching since their early semesters. However, not all of the students are motivated to be teachers and most of the time their imagination of becoming teacher would change when entering the six semester. In this semester, they are introduced to the class-based teaching practicum in a class called Micro Teaching. Students normally face tensions as they experience moving from theories into practice for the first time, and this is a normal thing to happen. One example of the common tensions is the feeling of being trapped between what is expected according to the theories and what personal beliefs the students have toward teaching (Volkmann \& Anderson, 1998).

\section{Findings and Discussion}

This section explains the findings of revealing pre-service foreign language teachers' imagined professional identities. In analyzing their reflective journals, the researcher used Open coding, Axial coding, and Selective coding as the three main stages of grounded theory (Corbin \& Strauss, 1990). The Open coding associates coding different statements identified in the reflective journals that were directly connected to the professional imagined identities. After identifying and listing those related statements, the Axial coding was administered to connect the statements to the subgroups of the related category. Finally, Selective coding is used to validate the relationships of all categories and integrate them into three final categories using Xu's framework (2013) of imagined professional identities. The following is the presentation of the final categories and subcategories of imagined professional identities.

Table 2: The final categories and subcategories of pre-service foreign language teachers' imagined professional identities

\begin{tabular}{|c|c|c|}
\hline Initial categories & Subcategories & $\begin{array}{c}\text { Final categories } \\
\text { (Xu's } \\
\text { framework) }\end{array}$ \\
\hline $\begin{array}{l}\text { - Reliable teacher who can teach with } \\
\text { good English (grammar) and fluent in } \\
\text { speaking } \\
\text { - A good teacher in delivering the } \\
\text { materials and having good teaching } \\
\text { methods } \\
\text { - A competent teacher who can speak } \\
\text { and explain in English very well and } \\
\text { clearly. } \\
\text { A teacher who uses English correctly, } \\
\text { pronounce correctly, and speak } \\
\text { fluently } \\
\text { A teacher with good English who has a } \\
\text { lot of good teaching methods and good } \\
\text { classroom management }\end{array}$ & $\begin{array}{l}\text { Focusing on content } \\
\text { knowledge and teaching } \\
\text { pedagogy (the way of } \\
\text { teaching) }\end{array}$ & $\begin{array}{l}\text { Language } \\
\text { Expert }\end{array}$ \\
\hline
\end{tabular}


- A good teacher with good attitude and can guide the students to become good human beings

- A confident and loving person who is not only a teacher but also a parent because I know how it feels like to be in the dark and be saved by my teacher

- A teacher who is friendly and can build good relation with students

- An inspiring teacher who can bring joy and solution in the class

- A friendly and loveable teacher who facilitates the learning process

- A teacher who knows each student's condition and help them learn

- A cheerful and fun teacher so that my future students will feel relax when I am teaching and we can learn together

- A good teacher who knows how to
Focusing on aspects related to 'guiding students' minds, spirits, and pursuits" (Xu, 2013, p. 82)

Focusing on the students' learning process and Facilitator becoming a facilitator in the teaching learning process
Spiritual Guide facilitate student's learning, more as a learning companion.

- A teacher who can create two-way learning condition because learning is not only from a teacher as the main source of knowledge

- A loving teacher and students see me as their friend.

- A creative teacher who can facilitate innovation to students.

- A patient, disciplined, not strict, and understandable.

- A teacher who can always emphasize on the learning process, not only explaining the materials.

- A teacher who can understand what the students want and facilitate their learning needs so students can be happy when learning with me

From the above coding, the result shows that Xu's three categories of imagined professional identities appeared in the participants' reflective journals. One participant highlighted content knowledge and pedagogy that foreign language teachers have to have:

"I want others see me as a competent teacher who uses English correctly, pronounce correctly, and speak English fluently ... The language must be good first before teaching. I don't expect something that ends up being mocked by my future students because my English is not good ... just like some of the lecturers here" [participant 9, reflective journal]

This excerpt suggested that participant 9's imagined professional identity is as a language expert. According to her, a competent English teacher had to master good English involving correct pronunciation and fluent speaking. Furthermore, 
participant 18 also indicated that he had a language expert imagined identity for him as a FL teacher:

"I want others see me in the future as a good teacher with good English, you know a teacher who is able to speak correctly and fluently just like you, miss ... I also imagine to be a good teacher because I have a lot of good teaching methods and good classroom management. Those are needed right in managing good class." [participant 18 , interview]

In participant 18 , his imagined professional identity is formed from his personal experience and some examples he encountered that he believed to be good teaching practices.

In another case, there were two participants whose formation of the imagined professional identity was as a spiritual guide. Participants 4 and 14 revealed their imagined identity as spiritual guides as shown in the following reflective journals:

"In the future, I want others see me as a good teacher with good attitude and can guide the students to become good human beings. I think the main purpose of education in not about having academic knowledge. It is more about becoming good human beings in the society." [participant 4, reflective journal]

"I want others see me as a confident and loving person who is not only a teacher but also a parent for my future students because I know how it feels like to be in the darkness and be saved by my teacher." [participant 14 , reflective journal]

It is obvious that the two participants' imagined professional identity was as a spiritual guide as they highly focused on aspects related to "guiding students' minds, spirits, and pursuits" (Xu, 2013, p. 82). Furthermore, participant 14 brought her past experience when she was "in the darkness" and was helped by her teacher. Further interview was conducted to find out what she meant by "the darkness". She clarified that she experienced physical abuse by one of her teachers when she was in junior high school, and she got help from her other teacher. Participant 14's past experience is, therefore, authentic to her decision about what kind of teacher she wants to be in the future.

Further finding shows that the dominant imagined professional identity formed by the pre-service FL teachers in this study was as a learning facilitator, as shown by participant 11:

"I want others to see me as a good teacher who knows how to facilitate student's learning; more as a learning companion." [participant 11, reflective journal]

The above excerpt revealed two important words that indicated participant 11's formation of her imagined professional identity: facilitate and companion. Teaching, in her imagination, was more on giving students opportunity to undergo the process and get full assistance from the teacher. The similar identity was also shown by participant 12 below:

"In the future, I want others see me as a teacher who can create two-way learning condition ... I mean not like the traditional education ... the teacher is the center and the main source of knowledge, the students listen all the time. I want to facilitate students ... they are encouraged to explore 
and learn, like finding the unfamiliar words from reading by themselves. I will only facilitate them with dictionary or other things" [participant 12 , interview]

The traditional education concept influenced participant 12's perception on FL teacher and what he/she should be. It is clear that her imagined professional identity was as a facilitator. The fact that the dominant imagined professional identity chosen by the pre-service FL teachers in this study was as learning facilitator indicates that the pre-service teachers' concept of teaching is shifted from the traditional concept which emphasizes teacher control into recognition of self-initiated learning, in which teachers' main job is facilitating learning.

\section{Conclusions: Reflections, implications, and future studies}

In conclusion, this study attempts to reveal pre-service foreign language teachers' imagined professional identity. In spite of the complexities appeared in their beginning stage of teaching practice, these teachers were able to form their own imagined professional identity. Out of 19 teachers, 5 teachers form a language expert as their professional identity as a FL teachers. The other two brought their past experiences into the formation of their imagined identity as a spiritual guide. The learning facilitator becomes the most dominant imagined professional identity formed by the students.

There are some implications that may be taken in based on these findings. Helping pre-service teachers to reveal their imagined professional identity may help them survive in their initial teacher program. By holding on their imagined identity, they can reduce the reality shock and tensions when facing the ups and downs of their teaching practices. Besides, the imagined identities formed by the teachers present important suggestion for FL teacher educators in the way they introduce teaching profession for future pre-service FL teachers. It is recommended that FL teacher educators provide more opportunities for preservice teachers to better cultivate their formation of professional identity from various viewpoints, not merely based on imagination. It is also recommended for future researchers to further explore the transformation of these imagined professional identities once the pre-service teachers teach in schools.

\section{References}

Ary, D., Jacobs, L.C., \& Sorensen, C.K. (2010). Introduction to research in education (8th ed.). Belmont, CA: Wadsworth.

Avalos, B. \& De Los Rios, D. (2013). Reform environment and teacher identity in Chile. In D. B. Napier \& S. Majhanovich (Eds.), Education, dominance and identity (pp. 153-175). Rotterdam: Sense.

Beijaard, D. (1995). Teachers' prior experiences and actual perceptions of professional identity. Teachers and Teaching: Theory and Practice, 1(2), 281-294.

Burke, B. (2006). Theory meets practice: A case study of preservice world language teachers in U.S. secondary schools. Foreign Language Annals, 39 (1), 148-163. 
Chong, S., \& Low, E.-L. (2009). Why I want to teach and how I feel about teaching-formation of teacher identity from pre-service to the beginning teacher phase. Education Research Policy Practice, 8, 59-72.

Corbin, J. M., \& Strauss, A. (1990). Basics of qualitative research: Grounded theory procedures and techniques. Newbury Park, CA: Sage.

Darling-Hammond, L. (2008). Knowledge for teaching: What do we know? In M. Cochran-Smith, S. Feiman-Nemser, D. McIntyre \& K. Demers (Eds.), Handbook of research on teacher education: Enduring questions in changing contexts (3rd ed.) (pp. 1316-1323). New York: Routledge.

Franzak, J. (2002). Developing a teacher identity: The impact of critical friends practice on the student teacher. English Education, 34 (4), 258-280.

Gee, J. P. (2000). Identity as an analytic lens for research in education. Review of Research in Education, 25, 99-125.

Hammerness, K., Darling-Hammond, L., Bransford, J., Berliner, D., CochranSmith, M., McDonald, M., \& Zeichner, K. (2005). How teachers learn and develop. In L. Darling-Hammond \& J. Bransford (Eds.), Preparing Teachers for a Changing World (pp. 358-389). San Francisco: Jossey-Bass.

Heigham, J., and Croker, R. A. (Eds.). (2009). Qualitative research in applied linguistics: A practical introduction. Basingstoke: Macmillan Publishers Ltd.

Olsen, B. (2010). Teaching for success. Developing your teacher identity in today's classroom. Boulder/London: Paradigm Publishers.

Pillen, M., Beijaard, D. \& den Brok, P. (2013). Tensions in beginning teachers' professional identity development, accompanying feelings and coping strategies. European Journal of Teacher Education, 36(3), 240-260.

Walkington, J. (2005). Becoming a teacher: Encouraging development of teacher identity through reflective practice. Asia-Pacific Journal of Teacher Education, 33(1), 53-64.

$\mathrm{Xu}, \mathrm{H}$. (2013). Exploring the institutional and professional role cognitions of EFL teachers in junior high school. Beijing: Foreign Language Teaching and Research Press. 